\title{
The Common Thread: Diversion in Juvenile Justice
}

\author{
Franklin E. Zimring $\dagger$
}

\section{TABLE OF CONTENTS}

I. Diversionary and Interventionist Justifications for

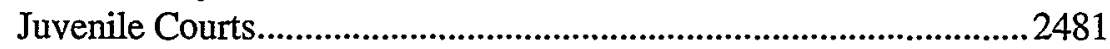

A. Diversion: The Forgotten Foundation ......................................2483

II. The Aims and Means of the Early Juvenile Courts ..........................2485

III. The Juvenile Court and the Rule of Law ........................................ 2486

IV. Diversion in the Modern Court ....................................................2489

A. Modern Reform: The Juvenile Justice and Delinquency Prevention Act of 1974 ........................................2489

B. Diversion and the Punitive Assault on Juvenile Justice .............2490

Figure I. Trends in Incarceration for Juveniles (14 to 17 year olds)

and Young Adults (18 to 24 year olds) ...........................................2492

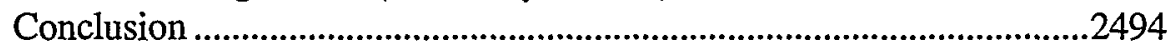

Copyright $\odot 2000$ Franklin E. Zimring. California Law Review, Incorporated (CLR) is a California nonprofit corporation. CLR and the authors are solely responsible for the content of their publications.

$\dagger \quad$ William G. Simon Professor of Law, School of Law, University of California, Berkeley (Boalt Hall), and Director, Earl Warren Legal Institute, University of California, Berkeley. A revised version of this Essay will appear in A Century of Juvenile Justice, edited by Margaret Rosenheim, Bernadine Dohrn, David Tanenhaus, and Franklin Zimring, in 2001. My debts are large for the help 1 received on this short Essay. The research reported was supported by a grant from the MacArthur Foundation network on adolescent development and juvenile justice, of which I am a member. David Tanenhaus of the University of Nevada at Las Vegas was my expert guide to the literature of the late nineteenth and early twentieth century on the rhetoric of reform. James Allison, then a graduate student at the Jurisprudence and Social Policy Program (JSP) at Boalt Hall, did the analysis of incarceration rates reported in Figure 1. Margaret Rosenheim of the University of Chicago, Steven Schlossman of Carnegie Mellon, Raymau Solomon of Rutgers (Camden), Kay Levine of JSP, and Virginia Mellema of JSP all provided helpful reading of an earlier draft. 


\title{
The Common Thread: Diversion in Juvenile Justice
}

\author{
Franklin E. Zimring
}

A central objective of those who created the juvenile court was to protect young delinquents from the destructive punishments of the criminal justice system. This promotion of juvenile court as a diversion from criminal justice is distinct from more ambitious programs of "child saving" intervention because avoiding harm can be achieved even if no effective crime prevention treatments are available. This essay shows diversion has been an important motive in juvenile justice from the beginning, and became the dominant purpose of a separate juvenile court after In Re Gault in 1967. The past thirty years have been the juvenile court's finest hour as a diversion project; the rate of juvenile incarceration has been stable, while incarceration of young adults has soared.

"The first idea that should be grasped concerning the juvenile court is that it came into the world to prevent children from being treated as criminals."

-Miriam Van Waters

The celebration of the Centennial of the Juvenile Court is not without its ironies. On the one hand, the institution has been a spectacular success in the United States and throughout much of the world. A juvenile court exists to deal with youthful law violators in all fifty states. No developed nation tries its youngest offenders in its regular criminal courts, and almost all the institutions that have been created in Europe, Japan, and the Commonwealth nations have been explicitly modeled in their language, procedures, and objectives on the American Juvenile Court. ${ }^{2}$ Of all legal institutions in Anglo-American history, the Juvenile Court has achieved the

1. Miriam Van Waters, The Juvenile Court from the Child's Viewpoint, in THE CHILD, THE Clinic and the Court 217, 217 (Jane Addams ed., 1925).

2. See Elmar G.M. Weitekamp et al., Institute of Criminology University of Tuefenger, International Comparison of Juvenile Justice Systems: Report to the National Academy of Sciences, (July 1999) (unpublished report, on file with author) for an English language survey of juvenile justice in 15 nations. See Akira Morita, One Hundred Years of Juyenile Law IN JAPAN-AN Historical \& Cross-cultural Dialogue (forthcoming 2001). 
widest acceptance among the diverse legal systems of the industrial democracies.

On the other hand, the philosophy of state intervention that has been most prominently associated with the creation of the court had been effectively discredited for at least a generation before the centenary. Variously called "child saving," "the omnibus theory of delinquency," and, most memorably, "the rehabilitative ideal," the original justification we remember of the Juvenile Court was as an institution that would intervene forcefully in the lives of all children at risk to effect a rescue. ${ }^{3}$ Informal proceedings were preferred to formal ones so that the delinquent's needs could be determined. ${ }^{4}$ Broad and vague definitions of delinquency were favored so that all youth who needed help would fall within the new court's jurisdiction. ${ }^{5}$ Large powers could be exercised in all cases so that help could be delivered to the deserving.

By the mid-1960s, the naive arrogance of the rehabilitative ideal had been exposed, ${ }^{6}$ never again to rule unchallenged in the Juvenile Courts. Yet the court has thrived since the 1960 s just as it had before. Was this postchild-saving Juvenile Court just an empty shell, an institution that had outlived its mission but continued to function on sheer momentum? Or is the Juvenile Court a chameleon, taking on new justifications and theories of function as old theories die? If so, why is this particular judicial weather vane so universally popular?

A substantial step toward understanding both the institutional status and justifying rationale of the modern juvenile court is to revise our view of the original justifications of the new court for delinquent children. I think that two justifications existed from the start for creating a Juvenile Court, and I shall call these two different policies the diversionary and interventionist justifications for a separate children's court. The diversionary goal of the court was to save kids from the savagery of the criminal courts and prisons. The interventionist goal was to create programs that would rescue delinquents from crime and truancy. The diversionary justification for juvenile court was always the most important of the two rationales, and it remains so today.

In the foundational period of the Juvenile Court, when different groups formed coalitions for different reasons, and when many reformers had multiple reasons to support a new court, the diversionary critique of criminal court processing of minors was always stronger and more widely accepted than the interventionist vision of the court. When it much later

3. See Anthony M. Platt, The Child Savers: The Invention of Delínquency 3-14 (1969).

4. See Franklin E. Zimring, The Changing Legal World of Adolescence 30-35 (1982).

5. See id. at 35 .

6. See, e.g., Francis A. Allen, The Juvenile Court and the Limits of Juvenile Justice, in THE Borderland of Criminal Justice 42, 49-54 (Francis A. Allen ed., 1964). 
became apparent that some elements of the interventionist justification were in conflict with both the realities of court function and with the principles of legality and proportionality, the diversionary rationale for the court emerged as the central explanation for the court's separate operation. These diversionary principles of juvenile justice are well suited both to a modern theory of adolescent development and to principles of procedural fairness and proportionality in legal response to youth crime. My goal in this Essay is to show both the continuity and coherence of the diversionary rationale for juvemile courts through the first 100 years of their history.

Part I of this Essay sets out the two discrete justifications for creation of a juvenile court and provides documentation of the diversionary agenda of turn-of-the-century reformers. Part II shows the extent to which the major programmatic elements of early juvenile justice were consistent with diversionary justifications and methods. Much of the work of the Juvemile Court, throughout its existence, was aimed at allowing kids to grow up in community settings. Part III addresses the modern concept of juvenile justice as reflected in two leading Supreme Court cases: In re Gault ${ }^{7}$ and In re Winship. ${ }^{8}$ Only the diversionary theory of juvenile court could accommodate due process rules without sacrificing youth welfare. Part IV concerns the contemporary understanding of juvenile justice as a passive judicial virtue. I demonstrate that the effectiveness of juvenile courts in protecting youth from full criminal pumishment is the heart of the reason the court has so many contemporary enemies.

\section{I}

\section{DIVERSIONARY AND INTERVENTIONIST JUSTIFICATIONS FOR JuVENILE COURTS}

Those who put their hopes in a new juvenile court to assume responsibility over young offenders had two reasons to assume the new court would be an improvement on the criminal processing of children. The first belief was that a child-centered juvenile court could avoid the many harms that criminal punishment visited on the young. The reformers found penalties unnecessarily harsh, and considered places of confinement to be schools for crime that corrupted the innocent and confirmed the redeemable in the path of chromic criminality. From this perspective, the first great virtue of the juvenile court was that it would not continue the destructive impact of the criminal justice system on children. This theory of justification for juvenile court, the diversionary rationale, argues that the new court could do good by simiply doing less harm than the traditional criminal processes. And every single one of the new court's prominent supporters believed the criminal courts to be destructive instruments best avoided.

7. 387 U.S. 1 (1967).

8. 397 U.S. $358(1970)$. 
The signal characteristic of a diversionary argument for juvenile justice is its attention to the harmful nature of criminal punishment for the young. A classic and nearly complete litany of the harms of the criminal law comes on the first page of Juvenile Court Judge Tuthill's 1904 account of the treatment of delinquents prior to reform:

Prior to 1899 little was done in Illinois, and, so far as I know, in any other State in the Union, that was not wrongly done by the State toward caring for the delinquent children of the State. No matter how young, these children were indicted, prosecuted, and confined as criminals, in prisons, just the same as were adults pending and after a hearing, and thus were branded as criminals before they knew what crime was. The State kept these little ones in police cells and jails among the worst men and women to be found in the vilest parts of the city and town. Under such treatment they developed rapidly, and the natural result was that they were thus educated in crime and when discharged were well fitted to become the expert criminals and outlaws who have crowded our penitentiaries and jails. The State had educated innocent children in crime, and the harvest was great. ${ }^{9}$

A similar rhetoric is reflected in accounts of the criminal justice system issued before and after the founding of the court by every one of the major public figures in the movement. William Stead speaks of a police station in which "urchins of ten and twelve who have been run in for juvenile delinquency have found the police cell the nursery cradle of the jail."10 Judge Hurley, who drafted the Illinois Juvenile Court law, described the criminal processing of children as "a solemn farce," that "[s]ociety has to answer for millions upon millions of law-made criminals."12 The criminal court was the common enemy that launched juvenile courts in America.

The diversionary justification for juvenile court can easily be contrasted with the second justification for the new court: what I wish to call the interventionist rationale. While the diversionary approach promised the avoidance of the criminal court's harms, the interventionist argument emphasized the positive good that new programs administered by child welfare experts could achieve. A child-centered court was an opportunity to design positive programs that would simultaneously protect the

9. Richard S. Tuthill, History of the Children's Court in Chicago, in CHILDREN's Courts IN the U.S.: Their Origin, Development, and Results 1, 1 (Richard H. Ward \& Austin Flower eds., AMS Press 1973) (1904).

10. William T. Stead, If Christ Came to Chicago! 20 (Chicago Historical Bookworks 1990) (1894).

11. Judge Timothy D. Hurley, Origin Of The Illinois Juvenile Court Law, in The Child, The Clinic AND THE CouRT, supra note 1, at 320, 320-21.

12. Id. at 321 . 
community and cure the child. This was the notion of child saving that made the court's early justifications seem so extrenie.

While the diversionary and interventionist justifications are conceptually quite distimct, there seems to have been little awareness at the court's founding that these two approaches to justifying the new court might conflict. ${ }^{13}$ The same people who believed in the diversionary virtues of a new court affirmed its interventionist potential as well. ${ }^{14}$ And because there was no contemporary awareness of potential conflict, the court's supporters did not have to choose between these separate but attractive rationales for the new institution.

But the diversionary rationale had several obvious advantages over an interventionist theory as a justification for an untested reform. In the first place, the new court could be counted on to achieve social good whether or not its treatment interventions worked. Avoiding the harms of the criminalization of children was a near-term benefit, whatever the programmatic potential of the new court's interventions might prove to be. A second advantage of a diversionary perspective is the way that doing less harm fit the shape and orientation of the new court's major tool, probation. Community supervision is rarely an heroic intervention; it does not take extensive power over the lives of young offenders when compared to jails, prisons, and work camps. It is also, in addition to its high moral principle, a method of responding to official delinquency that is relatively cheap.

At every level of discourse from prochild rhetoric to economic selfinterest, the diversionary perspective was monumentally attractive to those who were organizing a new court. It was an argument for juvenile courts without any known opponents or identified disadvantages, a foundation for the new court that was too obvious to be remembered clearly as a distinctive justification for change.

\section{A. Diversion: The Forgotten Foundation}

If the diversion of youth from the rigors of criminal punishment was a dominant motive for the new court, why does this justification not play a larger role in the historical accounts of the creation of the court? While diversionary motives dominate the contemporary accounts of the court's early years, these efforts to reduce the gratuitous harms of the criminal court do not receive much notice in the historical critiques of the court that appeared in the 1960s and 1970s. ${ }^{15}$

13. See, e.g., Julian Mack, The Juvenile Court, 23 HARv. L. Rev. 104 (1909) (discussing the juvenile court's ability to protect children from the stigma of criminalization as well as the court's ability to intervene to train the child properly).

14. See, e.g., id.

15. Compare The Child, the Clinic and the Court, supra note 1, with Platt, supra note 3, and Steven Schlossman, Love and the American Delinquent: The Theory and Practice of "Progressive" JuVEN1Le Justice, I825-1920 (1977). 
Part of the reason later scholars give more account to the interventionist theory of juvenile justice is that such a claim was both novel and controversial, while child protective sentiments are so widely shared as to be without any singular importance at any particular historical moment. The prochild sentiments that support diversion in 1899 do not set that era far off from 1940 or 1980 . The claims of interventionist prowess are considered by contrast a striking historical artifact by the 1960s and 1970s, if not before. ${ }^{16}$

Many accounts of the court's justifications were written by judges with a vested interest in expanding the powers and prestige of this new office; this fact provides another historical explanation for the inflated emphasis on interventionist dogma. Avoiding harm for children is a modest objective, indeed, when compared to the therapeutic rescue of those about to fall to the lower depths. The rhetoric of Judge Mack, for instance, seems prone to such claims; ${ }^{17}$ even the writing of Judge Lindsey, a noninterventionist for his time, was full of accounts of judicial rescue. ${ }^{18}$

However understandable the failure of those who study court history to give sufficient attention to diversionary motives, this gap has led to a variety of unfortunate consequences. In the first instance, much late twentieth-century work underestimates the capacities and misrepresents the motives of founding figures such as Jane Addams, Lucy Flower, and Julia Lathrop. ${ }^{19}$ In the second place, the failure to give prominent attention to avoiding criminal stigma for kids leaves these later histories with no explanation for the worldwide popularity of the juvenile court for delinquents. Undoubtedly it was the avoidance of criminal justice damage, not an interventionist claim to judicial power, that spread the juvenile court gospel across the world in the early years of the century. It was this type of diversionary child saving that generated nearly universal appeal of a court for children in the modern industrial states.

The third problem with ignoring the diversionary rationale for juvenile court is that it makes it impossible to understand much of the developing nature of juvenile justice in the first half of the twentieth century by referring to the court's original justification, because the court that evolved was more suited to the passive virtues of diversion than to any nuassive campaign of intervention in the lives of young delinquents.

16. See Allen, supra note 6.

17. See Mack, supra note 13.

18. See Schlossman, supra note 15 , at 55-57.

19. See, e.g., PLATT, supra note 3. 
II

\section{The Aims and Means of the Early Juvenile Courts}

The early years of the twentieth century were not a period when new forms of intensive behavioral therapies were applied to either adults or juveniles brought before the Bar of Justice. The most serious of the commitment options open to the Juvenile Court was the state reformatory or training school, an institution with a nineteenth-century program and a dismal reputation for innovation or behavioral impact. ${ }^{20}$ One searches the record in vain for major figures in the creation of the court who put their hopes in state schools of the industrial variety as an arena for child saving. ${ }^{21}$ The sole virtue of the reform school was the fact that it was not a prison. No reformer bore hopes for intervention on the positive capacity of the state training school. Instead, the early twentieth-century reformers rested their programmatic hopes on social and educational change generally, as well as on community-based probationary supervision for the delinquent in his family setting. ${ }^{22}$ Compulsory education and child labor laws, not the operations of juvenile court, were the major objectives of progressive youth policy. ${ }^{23}$

Within the juvenile court, the major programmatic advantage was probation. ${ }^{24}$ The goal of the reformers in the words of Jane Addams was "a determination to understand the growing child and a sincere effort to find ways for securing his orderly development in normal society."25 Steven Schlossman's study is the best published analysis of early juvenile court work and indicates that probation was twice as likely in Milwaukee as all other court outcomes combined in $1908 .{ }^{26}$

The emphasis on probation and community-based supervision fits nicely with a diversionary justification for juvenile courts. The job of the court is first not to harm the youth and then to attempt to help in community settings. This same programmatic emphasis does not mesh well with the romantic rhetoric of child saving. Probation is at its essence an incremental social control strategy, one that relies on the basic health and functionality of the subjects' community life.

Even the more ambitious plans of probation advocates to get involved with families and schools were low-intensity social control, particularly

20. See Julia C. Lathrop, The Background of the Juvenile Court in Illinois, in THE CHILD, THE Clinic AND THE CouRT, supra note 1, at 290.

21. See Schlossman, supra note 15, at 64-66.

22. See Ben B. Lindsey, Colorado's Contribution to the Juvenile Court, in THE CHILD, THE Clinic, AND THE CourT, supra note 1, at 274.

23. See Jane Addams, Introduction to THE Child, The Clinic AND THE Court, supra note 1, at 2.

24. See Lindsey, supra note 22 , at 274.

25. See Addams, supra note 23 , at 2.

26. See Schlossman, supra note 15 , app. 2 , tbl. 2 at 202 . 
given the tiny budgets and volunteer staffs characteristic of the early years of the juvenile court. The only new programs that fit the profile of child saving were the secure "parental schools" for truants that hoped to marry coercive means to educational objectives and juvenile detention. ${ }^{27}$ Both programs were sufficiently coercive to create tension with a pure diversionary agenda, but only the truancy programs approach the pattern one would expect to find in a court pursuing an aggressive interventionist philosophy.

The other major increase in social control was the explicit extension of all juvemile court sanctions to noncriminal behavior such as disobedience to adults, truancy, and curfew. ${ }^{28}$ Clearly, the court was not extending jurisdiction in this direction in the name of diversion. But the same jurisprudence of childhood dependency that supported these powers for status offenders also was a foundation for keeping young offenders out of criminal courts. ${ }^{29}$ So there was no direct clash between status offender jurisdictions and diversion from criminal court for other developments.

There is one final respect in which the role of the juvenile court was more modest in the reform imagination than in some of the court's interventionist rhetoric. If child labor regulation and public education are the important public law enterprises of the new order for the young, both of these are centered in governmental operations that start apart from juvenile court. So too does the settlement house created by Jane Addams and other nongovernmental community institutions to educate and support families. To do less harm than criminal courts, the new legal setting for delinquency did not need to be a superpower, and it was not.

III

\section{The Juvenile Court AND THE Rule of LAW}

Only after two-thirds of the twentieth century had passed did the United States Supreme Court consider the procedural protections that due process required when accused delinquents were in jeopardy of secure confinement in state institutions. One important issue in In re Gault, the case that decided most of these issues in 1967, was the need for informality if the court was to achieve its child-saving mission. ${ }^{30}$ Writing in dissent, Mr. Justice Harlan thought that rigid due process requirements could disserve the goals of traditional juvenile justice. While the Gault majority held that due process requires recognition of a privilege against

27. See Editors' Introduction to JefFrey Fagan \& Franklin E. Zimring, The Changing BordERS OF JUVENILE JUSTICE (2001).

28. See Zimring, supra note 4, at 35-37.

29. See id. at 35-40.

30. See In re Gault, 387 U.S. 1, 25-26 (1967). 
self-incrimination, the right to confront witnesses, and the right to crossexamination, Justice Harlan argued that

quite unlike notice, counsel, and a record, these requirements might radically alter the character of juvenile court proceedings. The evidence from which the Court reasons that they would not is inconclusive, and other available evidence suggests that they very likely would. At the least, it is plain that these additional requirements would contribute materially to the creation in these proceedings of the atmosphere of an ordinary criminal trial, and would, even if they do no more, thereby largely frustrate a central purpose of these specialized courts. ${ }^{31}$

His suggestion was that such procedures could jeopardize the special substantive mission of the juvenile court. Yet, Justice Fortas, writing the majority opinion, argued that there was no serious tension between the therapeutic intentions of the juvenile court and procedural protections for the accused who come before the court:

While due process requirements will, in some instances, introduce a degree of order and regularity to Juvenile Court proceedings to determine delinquency, and in contested cases will introduce some elements of the adversary system, nothing will require that the conception of the kindly juvenile judge be replaced by its opposite... . $^{32}$

Rather than take one side in this debate, I wish to argue that the contrast between interventionist and diversionary theories of the court will decide whether there is tension between the court's objective and due process standards. For an informal and interventionist juvenile court, standards of proof and defense lawyers are a major drawback to identifying children in need and providing them with help. Due process is therefore a major handicap to achieving such an informal juvenile court. But if saving kids from the gratuitous harms inflicted by the criminal process is the aim, there is no inherent conflict between due process and the court's main beneficial functions.

The best illustration of the tension between due process and an interventionist court is the issue raised by the case of In re Winship in 1970. The state of New York allowed a petition alleging delinquency to be sustained in Juvenile Court if the state proved such facts by a preponderance of the evidence, the usual standard of proof in civil trials. ${ }^{33}$ The appellants, using Gault as authority, argued that delinquency could only be established

31. Id. at 75 (Harlan, J., dissenting) (citations omitted).

32. Id. at 27.

33. See In re Winship, 397 U.S. 358, 360 (1970). 
by proof of its constituent facts beyond a reasonable doubt. The Supreme Court agreed with this conclusion. ${ }^{34}$

But what is the justification for requiring proof beyond a reasonable doubt in criminal cases? The usual law day speech tells us that erroneous acquittals are less socially harmful than erroneous convictions: "It is better that ten guilty men go free than that one innocent man gets convicted!" However, if the Juvenile Court is there to help delinquents, it does not make sense to say "It is better that ten kids who need help do not get help than that one kid who does not need help is erroneously assisted!" If the dominant purpose of juvenile justice is forceful intervention for the child's own good, the rules in Gault and Winship were a decisive rejection of the juvenile court's jurisprudence.

Every aspect of due process protection is consistent with a diversionary theory of juvenile justice. If the principle benefit of juvenile court is that it keeps kids from the destructive impact of the criminal courts, this benefit may be provided whether or not the new court makes a formal sanctioning decision in a particular case. A high burden of proof or a children's lawyer will not cost the court its diversionary function.

The diversionary theory of juvenile justice also fits better with the portrait of the modern juvemile justice system that Justice Fortas presented in Gault. The recognition in cases such as Gault and Winship that terms such as "delinquent" carry stigma and that juvenile court sanctions may function as punishments poses no threat to the diversionary rationale. As long as the juvenile court can be seen as the lesser of evils, a diversionary view of the court is both sophisticated and pragmatic, and need not deny that punitive motives might color sanctioning decisions in the children's court.

The interventionist view of court processes was always more fragile because it required that interventions be characterized positively in order to justify the court's existence. To label as "punishment" what the juvenile court does to delinquents is to deny the truth of a central premise of the interventionist theory.

Viewed in this light, the majority opinion in Gault rejected one enduring rationale for a separate juvenile court and elevated a second theory to supremacy. The Juvenile Court that the United States Supreme Court approved was child protective chiefly by keeping kids out of prisons and jails. ${ }^{35}$ Such an institution could be parsimonious with its own punishments, restricting them to cases with strong evidence and fair procedures, without threatening its own substantive mission. The arrogance of unqualified judicial power was not necessary to this version of the court's purposes. Because of In re Gault in 1967, diversion was the approved

34. See id. at 368.

35. See In re Gault, 387 U.S. at 22. 
version of juvenile justice in the United States, and probably in the rest of the developed world. Some Juvenile Court judges might have regretted the way Justice Fortas deconstructed the interventionist facade of juvenile courts. But the Gault majority did not undo or completely reorient the court that Grace Abbott, Julia Lathrop, and Jane Addams supported. The diversionary institution these founding figures sought had passed the tests of In re Gault and In re Winship with flying colors.

\section{IV}

\section{DIVERSION IN THE MODERN COURT}

Like many other American institutions, the juvenile court, itself just an experiment at the beginning of the century, has witnessed changes to its clientele, to its political and legal constituencies, and in its operations over the twentieth century. But the core concern of the court, "to prevent children from being treated as criminals, ${ }^{36}$ is just as clear in 1999 as in 1899. As the usual period of schooling and economic dependency in adolescence has lengthened over the twentieth century, the maximum age for juvenile court delinquency first drifted upward to the eighteenth birthday in most states, and then stayed at eighteen in most states, reflecting an age boundary close to the inode for high school graduation.$^{37}$ The period of semiautonomy that now spans most of the teen years is spent for the most part in the delinquency jurisdiction of juvenile courts. ${ }^{38}$ This Part will show that recent policy developments and conflicts about the modern juvenile court reflect a consistent diversion orientation of juvenile justice.

\section{A. Modern Reform: The Juvenile Justice and Delinquency Prevention Act of 1974}

The announcement of due process requirements discussed in the previous Part was closely followed by the first major federal legislation designed to influence the substantive content of state juvenile justice policy by providing financial rewards to state systems that met the federal standards ${ }^{39}$ The two major targets of the 1974 Juvenile Justice legislation fit quite comfortably under a traditional diversionary view of the court's objectives. The first push of the federal law was to remove minors from American jails and prisons ${ }^{40}$ The protective segregation of children had been at the heart of the diversion agenda in $1899 .{ }^{41}$ While the original reformers would have been disturbed to find that seventy-five years of

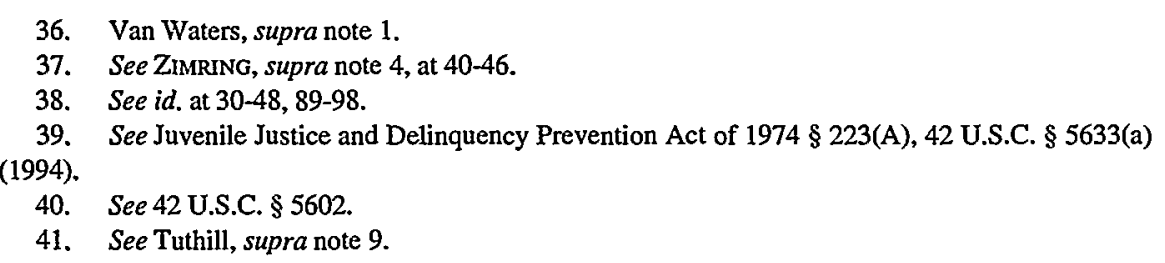


American history had not yet achieved this primitive reform, the continuing struggle to attain separate housing for kids in confinement was a purely diversionary reform $\mathrm{m}$ obvious accord with the original vision of the court.

So, too, was the second major objective of the 1974 legislation, the deinstitutionalization of status offenders. ${ }^{42}$ The saga of the status offender was one of the great failings of the interventiomst theory of juvenile courts. In the original legislation, the noncriminal behaviors later to be called status offenses were simply additional behaviors that could justify a finding of delinquency as well as any placement that the juvenile court could order for a delinquent. ${ }^{43} \mathrm{Kids}$ who ran away from home or were disobedient or truant could be committed to the same institutions as the juvenile burglar and auto thief. ${ }^{44}$

There were two problems associated with secure institutional confinement for noncriminal misbehavior: It was grossly unfair and it was manifestly ineffectual. By 1974, nearly all in the youth welfare profession agreed on the need to scale back on this branch of the rehabilitative ideal. ${ }^{\text {s }}$ The direct conflict between not allowing the Juvenile Courts to order secure institutions for truants and an interventionist theory of the court is obvious, because the interventionist judge claimed broad power to do whatever the troubled child needed.

However, there is no necessary conflict between limits on the coercive interventions allowed for noncriminal behaviors and a diversionary theory of juvenile justice. Simply because reformers wish to keep adolescent law violators out of jail does not mean that the same observers support serious punishment for noncriminal kids. Quite the opposite. While juvenile court treatments for young offenders are found in most developed nations, the strong interventionist claim that justified training schools for truants was nowhere near as widespread in popularity as the juvenile court itself. $^{46}$ I believe that foreign courts did not adopt such policies because diversionary theories did not require thein. The federal legislation, like the constitutional cases that preceded it, can be seen as endorsing diversion as the theory of the modern court to the exclusion of interventionism.

\section{B. Diversion and the Punitive Assault on Juvenile Justice}

Perhaps the most dramatic evidence of the efficacy and importance of diversionary policies in modern juvenile justice is the sustained attack on the modern juvenile court by the political forces of law and order. ${ }^{47}$ At the

\footnotetext{
42. See 42 U.S.C. § 5711(a).

43. See ZimRING. supra note 4 , at $35-40$.

44. See id. at $30-48,61-76$.

45. See id. at 71-75.

46. See Grace Abbott, History of the Juvenile Court Movement Throughout the World, in THE ChILd, THE Clinic, AND THE CouRT, supra note 1, at 267, 267-73.

47. See Franklin E. Zimring, American Youth Violence ch. 1 (1998).
} 
federal level, Republican legislative majorities have been attempting to use federal financial incentives, pioneered in the Juvenile Justice and Delinquency Prevention Act of 1974, to push a series of standards designed to create more punitive sanctions within the delinquency jurisdiction of the juvenile court and easier transfers of serious juvenile offenders to criminal courts. ${ }^{48}$

The rhetoric in support of this legislation uses new phrases such as "accountability" and "graduated sanctions" to describe the desired juvenile court outcomes. ${ }^{49}$ But the common enemy of the transfer policies and the harsher juvenile court punishments proposed in the legislation is a juvenile court tradition that seeks to avoid permanent stigma and disfiguring punishments of delinquents. The terms of reprobation aimed at the court by its critics on the right-terms such as "revolving door justice," "slap on the wrist," "Kiddie Court"-are an acknowledgment of the court's diversionary intent. To the extent that the attacks by its critics are based on empirical truth, those assaults pay tribute to the efficacy of a court that has been seeking to avoid the harshest outcomes for its caseload throughout the twentieth century.

But is there any truth to the rumor that juvenile courts protect delinquents from destructive punishments? A peek behind the rhetoric of current debates about responses to youth crime reveals very little analysis comparing sanctions for similar offenses across juvenile and criminal courts. Moreover, ignorance of the impact of juvenile court processing on punishnient outcomes for different types of crime is not a recent problem. ${ }^{50}$ My own belief is that juvenile courts have always generated some diversionary benefits to many classes of young offenders, but that the size and distribution of diversionary benefits varies by period, by the personality and style of the defendant, and by type of offense. There is no excuse for the nearly nonexistent research base on this important issue, particularly because this situation turns determining the aggregate impact of juvenile court case processing on punishments into a guessing game.

My best guess is that the protective impact of a diversionary juvenile court on sanctions for youth crime is largest when punitive policies are at their most dominant in criminal courts, in other words, in ages like the American present. During the 1950s and 1960s, just before the scalding critiques of Francis Allen and others, it is not clear that the combination of juvenile courts and youth corrections delivered less secure confinement to juveniles in many systems than did the criminal courts to the next oldest group of offenders. But the larger the punitive bite of the criminal court

48. See S. 10, 105th Cong. (1997); H.R. 3, 105th Cong. (1997).

49. See, e.g., S. REP. No. 105-108 (1997); H.R. REP. No. 105-86 (1997).

50. See Peter W. Greenwood et al., Age, Crime, and Sanctions: The Transition from JUVENILE TO ADULT COURT (1980). 
system becomes, the more likely it will be that a separate court for the youngest offenders takes some of the bite out of the state sanctions that juvenile offenders receive.

Figure 1 provides fairly careful estimates of public facility confinement for youth age 14-17 and young adults age 18-24 for 1971, 1991 and 1995. For the 14-17 group, I combine juvenile detention facilities, training schools, camps, etc., with the number of 14- to 17-year-olds in prisons and jails. Only the juvenile facilities are under the control of the Juvenile Court, but total secure incarceration is the best measure of total governmental control. The figure is formatted with each age group's rate in 1971 expressed as 100 so that the changes over time are emphasized.

\section{FiguRE I.}

TRENDS IN INCARCERATION FOR JUVENILES (14 TO 17 YEAR OLDS) AND YOUNG ADULTS (18 TO 24 YEAR OLDS)

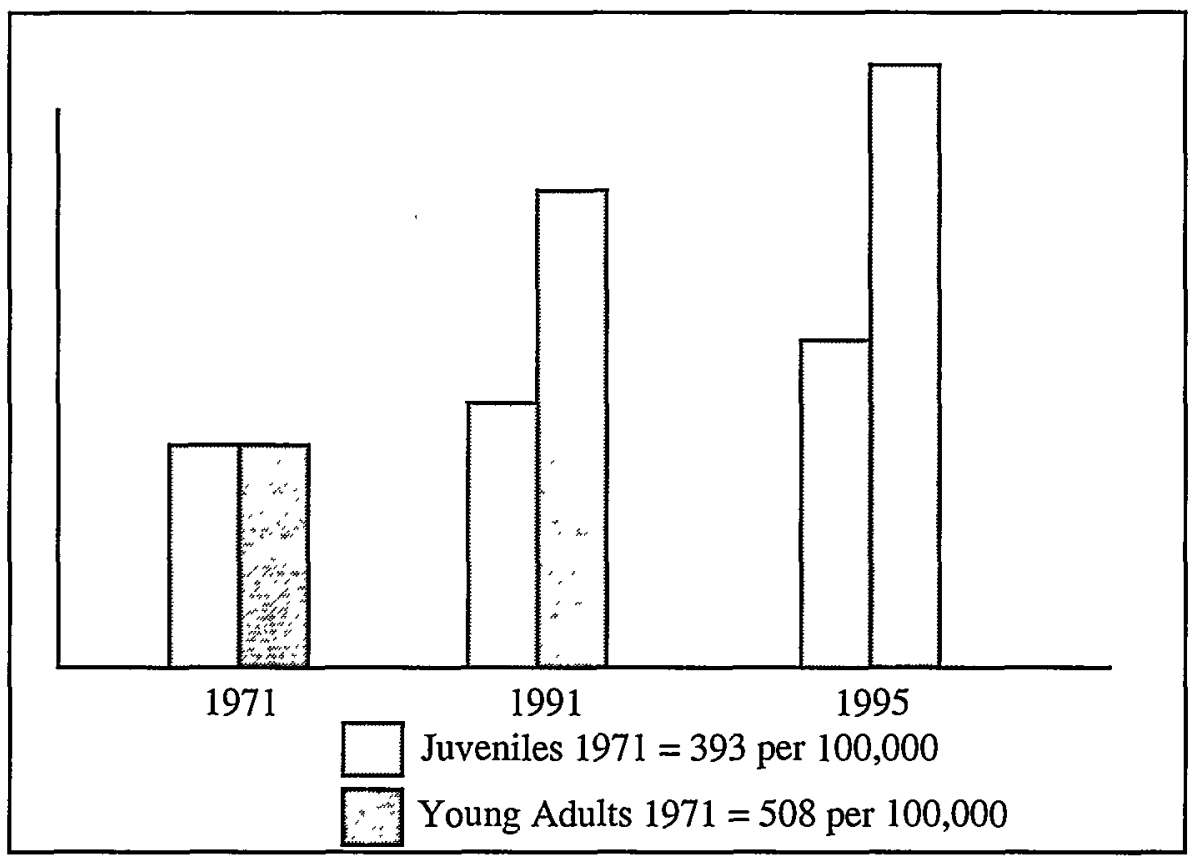

Sources $^{51}$

51. See BUREAU OF JUST. STAT., U.S. DEPT. OF JUST., CORRECTIONAL POPULATIONS IN THE UNITED STATES 21 (1995); CRIM. JUST. RES. CTR, U.S. DEPT. OF JUST., SOURCEBOOK OF CRIM. JUST. STAT. 352-53 (1973); CRIM. JUST. RES. CTR., U.S. DEPT. OF JUST., SOURCEBOOK OF CRIM. JUST. STAT. 644-45 (1976); CRIM. JUST. RES. CTR, U.S. DEPT. OF JUST., SOURCEBOOK OF CRIM. JUST. STAT. 607 (1977); CRIM. JUST. RES. CTR, U.S. DEPT. OF JUST., SOURCEBOOK OF CRIM. JUST. STAT. 484, 503 (1999); Darrel K. Gilliard \& Allen J. Beck, Prison and Jail lnmates, 1995, BUREAU OF JUST. STAT. BULl., Aug. 1996; Caroline Wolf Harlow, Profile of Jail Immates, 1996, BUREAU OF JUST. STAT. SPECIAL REP, Apr. 1998; Kevin J. Strom, Profile of State Prisoners Under Age 18, 1985-97, BUREAU OF JUST. STAT. SPECIAL REP., Feb. 2000; Fax from Allen J. Beck, U.S. 
As the fine print in Figure 1 indicates, the incarceration rates for the two groups are not greatly different in 1971: the 18-to-24-year-olds have a jail and prison rate that is $28 \%$ higher than the total public incarceration rate of 14-to-17-year-olds. Trends after 1971 for the two groups diverge. The period 1971-1991 was not a typical interlude in the history of American crime policy. It was, instead, the period of the most substantial growth in the scale of imprisonment in the history of the Republic. ${ }^{52}$ Never was the pressure for confinement as consistent and substantial. ${ }^{53}$ Total confinement for the younger group increased by $21 \%$ while the incarceration rate of young adults more than doubled. By 1991, the difference in incarceration rates for the two groups was more than 2 to 1 , and this very substantial gap is one reason why those who had succeeded in radically altering punishments in criminal courts might have resented the stability in policy and outcome that occurred for younger offenders.

The pattern during the early 1990s is more coinplicated. The rate at which 14-to-17-year-olds were incarcerated grew alinost as much in the four years after 1991 as it did in the two decades prior to 1991. For that reason, it may look like a sigmificant shift toward toughness had finally taken hold. But the growth in young adult incarceration was much greater than in the younger age group, so that the gap between older juveniles and young adults actually widened in the early 1990 s. The incarceration rate per 100,000 grew by about 80 for the 14-17 group, and more than three times as fast for 18-24.

These data suggest that the diversionary objective of the juvemile justice systein insulated delinquents from the brunt of a high magnitude expansion in incarceration in the criminal justice system. Figure $I$ is one of the most dramatic demonstrations I have ever seen of how two separate courts can pursue quite different crime control policies over a sustained period of time. If diversion was an organizing principle of inodern juvenile justice, then the Juvenile Courts were keeping their promises through the 1970 s and 1980s in the Umited States.

Their consistent incarceration-limiting policy generated substantial political pressure on juvenile courts in the Umited States while the criminal

Department of Justice, Bureau of Justice Statistics, to Franklin E. Zimring, Professor, Boalt Hall School of Law (Oct. 26, 2000) (on file with author); Fax from the U.S. Department of Commerce, Bureau of the Census, to Franklin E. Zimring, Professor, Boalt Hall School of Law (Oct. 24, 2000) (on file with author); U.S. Department of Commerce, Bureau of the Census website, at http://www.census.gov (last visited November 10, 2000); see also Joseph Moone, Children in Custody 1991: Private Facilities, 2 OFF. OF JUV. JUST. \& DELINQ. PREVENTION FACT SHEET, Apr. 1993; Joseph Moone, Children in Custody 1991: Private Facilities, 5 OFF. OF JUV. JUST. \& DELINQ. PREVENTION FACT SHEET, Sept. 1993; Joseph Moone, States at a Glance: Juveniles in Public Facilities, 1995, 69 OFF. OF JUV. JUST. \& DELINQ. PREVENTION FACT SHEET, Nov. 1997.

52. See FrankLin E. Zimring \& Gordon Hawkins, The Scale of ImRPrisonment ch. 5 (1991).

53. See id. 
justice system experienced two and one half decades of uninterrupted penal expansion. ${ }^{54}$ Indeed, the data in Figure I suggest a new explanation for the flurry of legislative activity to create larger punishments for juvenile offenders. The usual account of juvenile crime legislation explains it as the concern of politicians and citizens with juvenile crime and violence. ${ }^{55}$ But the rate of serious juvenile violence has dropped steadily after 1994 and the attack on juvenile court has not let up. ${ }^{56}$

Figure I shows that the political forces that had produced extraordinary expansion through the rest of the penal system had been stymied in juvenile courts. In that sense, the under-eighteen population became the last sigmificant battleground for the "get tough" orientation that had already permeated the rest of the peno-correctional system. The exceptional diversionary performance of American juvenile courts in the 1970s and 1980s rendered the system vulnerable to the same attacks that had succeeded decades before in criminal justice.

So the angry assaults on juvenile courts throughout the 1990s are a tribute to the efficacy of juvenile justice in protecting delinquents from the incarcerative explosion that had happened everywhere else. The largest irony of the 1990s from a diversionary standpoint is that the Juvenile Courts were under constant assault not because they had failed in their youth serving mission, but because they had succeeded in protecting their clientele from the new orthodoxy in crime control.

\section{CONCLUSION}

For those who see adolescence as a stressful and experiment-laden transition to adulthood, growing up is the one certain cure for most juvenile crime. The policy objective that drew many adherents to the notion of a juvenile court conceived of it as a place in which it would be possible "to understand the growing child and ... to find ways for securing his orderly development in normal society." 57

In 1899 , a criminal justice system that removed youth from community settings and thrust them into lock-ups and jails was seen as a principal threat to adolescent development in normal society. For this reason, the juvemile court "came into the world to prevent children from being treated as criminals." This was and is "the first idea that should be grasped concerning the juvenile court." policy goal of tremendous durability, more humble in its ambitions and

\footnotetext{
54. See ZIMRING, supra note 47.

55. See id.

56. See id. at ch. 3 .

57. Addams, supra note 23 , at 2.

58. Van Waters, supra note 1 , at 217.

59. Id.
} 
closer to institutional reality than the interventionist agenda of juvenile justice ever was. The diversionary theory of juvenile court jurisdiction was never an alternative to helping juvenile offenders, but it was a more particular and more limited kind of help than plenary child saving. It was a modest, focused way of helping young offenders survive both adolescent crime and the experience of social control with their life chances still intact.

The historical record suggests that the diversionary juvenile court was a reform more worldly and sophisticated than scholars have yet acknowledged. The early history of juvenile court provides the basis for a jurisprudence of patience and restraint, an institutional commitment to do less harm than the criminal courts did to young offenders. This was a powerfully sensible idea in 1899. It still is. 
